\title{
A Defective Democracy: The Case of the United States
}

\author{
John Dreijmanis \\ Formerly Institut für Politikwissenschaft, Universität Bremen, Bremen, Germany \\ Email: dreijman@uni-bremen.de
}

Received 10 May 2014; revised 15 June 2014; accepted 30 July 2014

Copyright (C) 2014 by author and OALib.

This work is licensed under the Creative Commons Attribution International License (CC BY). http://creativecommons.org/licenses/by/4.0/

(c) (i) Open Access

\begin{abstract}
According to the six criteria of Wolfgang Merkel and Auriel Croissant to distinguish various political systems, the United States is a defective democracy, with increasing socio-economic inequality.

Keywords

Defective Democracy, Dominant Beliefs, Defects, United States, Gini Coefficient, Wolfgang Merkel, Auriel Croissant, Socio-Economic Inequality
\end{abstract}

Subject Areas: Politics, Sociology

\section{Introduction}

The United States and many of the Western European states have been traditionally regarded as democracies. On the other hand, such states as contemporary Belarus and Zimbabwe are classified as autocracies. It may be maintained that all democracies have some defects, some more than others, but some of them are defective democracies. This does not mean that the goal is a perfect or an ideal democracy [1]. It is rather the presence or the absence of certain criteria that are the determining factors [2]. There are many criteria by which to analyse various political systems.

The United Nations under the concept of "good governance" includes the following ten core principles: participation, the rule of law, transparency, responsiveness, consensus, inclusiveness, effectiveness, equity, efficiency, and accountability [3]. Abhishek Jain and Aarushi Jain have also ten core principles, seven of which are the same as those of the United Nations, plus ethics, service ethos, and predictability [4]. It is beyond the scope of this article to deal with all of these principles, some of which are essentially identical with the six criteria of Merkel and Croissant. Moreover, the latter criteria are more specific and therefore more applicable to the United States than those of the United Nations and Jain and Jain.

Wolfgang Merkel and Auriel Croissant use the following criteria to distinguish various political systems: legitimization of political power (Criterion 1), access to political power (Criterion 2), monopoly on political power 
(Criterion 3), structure of political power (Criterion 4), claim to political power (Criterion 5), and exercise of political power (Criterion 6) [5]. Before these criteria are applied to the United States, it is necessary to briefly analyse certain dominant beliefs.

\section{Federalism}

The American War of Independence (1775-1783) resulted in the overthrow of British rule and the creation of a republic. The colonials regarded their accomplishment as a revolution of global applicability. In the words of Thomas Jefferson: "A just and solid republican government maintained here, will be a standing monument and example for the aim and imitation of the people of other countries" [6]. James Madison was even more enthusiastic: "They accomplished a revolution which has no parallel in the annals of human society" [7].

From a historical perspective, however, the conflict with Britain was a "war of national liberation," not a revolution resulting in a fundamental socio-economic and political transformation as happened as a result of the French Revolution (1789-1799) and the Communist October, 1917 Revolution in Russia. Indeed, as Alexis de Tocquiville observed, Americans dreaded revolution "as the worst of misfortunes and that every one of them is inwardly resolved to make great sacrifices to avoid such a catastrophe" [8].

The colonials' fear of government was so strong that when they created a new political system under the 1787 Constitution, federalism, separation of authorities or powers, and checks and balances were regarded as devices for protecting freedom. This was well expressed by Madison: "In the compound republic of America, the power surrendered by the people, is first divided between two distinct governments, and then the portion allotted to each subdivided among distinct and separate departments. Hence a double security arises to the rights of the people. The different governments will controul each other: at the same time that each will be controlled by itself" [9]. Responsible government in the sense of the executive being accountable to the legislature was rejected in favour of the three parts being as autonomous as possible.

\section{Dominant Beliefs}

Three dominant beliefs have shaped and still shape to varying degrees the people's thinking and behaviourindividual initiative and responsibility, equality of opportunity, and freedom. The former is based upon the fear of government involvement in socio-economic matters, but its roots go back to the Pilgrim world view that "ensured that the unsuccessful would blame their own inadequacies" [10]. There is thus opposition to collective domestic action. Americans "prefer to see their society as a conglomeration of private individuals and entitled to pursue profit and pleasures as they choose" [11]. By privatizing social existence, the idea of collective purpose is avoided. Government "is seen solely as a coercive instrument, never adding to the nation's wealth or well-being but rather constricting efforts at innovation originating elsewhere" [12]. This has led to "disastrous consequences" [13]. It was not until the 1930s as a result of the economic depression that the American welfare state came into being. Comprehensive health care insurance for all people dates from only 2010.

Equality of opportunity and freedom consist of three components. There is equality of opportunity, not results. It is "competition for undefined goals with a minimum of political interference or, to put it the other way around, a political order just strong enough to give all members of society an equal choice to do as they please" [14]. In due time as more and more inequality developed the importance of equality of opportunity declined, and by the end of the twentieth century it had become largely a myth [15].

The second component is the Jeffersonian belief in the American achievement as an example for other countries to follow. This has also lost much of its exemplary force. However, it has remained a dominant belief as far as justifying wars and interventions abroad is concerned.

The third component is the desire to "expand the area of equality in freedom in order to maintain equality in freedom at home" [16]. The arena to accomplish this has "become world-wide" [17]. However, it has become increasingly limited to freedom.

\section{Defects}

According to Criterion 1, democracies are "legitimated by the principle of sovereignty of the people exercised against the background of freedom and equality” [2]. In a formal sense this is true, but its exercise is significantly limited by the constitutional requirement (Article V of the United States Constitution) that amendments 
need to be proposed by either two-thirds of both houses of Congress (the Senate and the House of Representatives) or when two-thirds of the state legislatures call a convention for that purpose. Amendments need to be ratified by three-fourths of state legislatures or by conventions in three-fourths thereof. These are excessive requirements and an important reason why to date there have been only twenty-six amendments. Unlike in Switzerland, which has initiatives and referenda, and also in Britain and Ireland in the case of referenda, there are no provisions for initiatives and referenda at the federal level. Quite aside from the people's increasing desire for more elements of direct democracy, there is also a psychological dimension.

The Swiss psychologist Carl G. Jung noted that Switzerland has avoided external wars for more than 400 years, because "we fight each other within the limits of law and constitution, and we are inclined to think of democracy as a chronic state of mitigated civil war" [18]. This is too strongly put, but his point is that by so doing the Swiss have succeeded in "introverting war" [18].

Criterion 2 provides that access to political power be through general, equal, free, and fair elections [19]. There are major defects concerning equality and fairness. In the Senate each state has two senators regardless of population (Article I, Section 3). Although the House of Representatives is based on the population of each state, except that each state shall have at least one representative (Article I, Section 2), the electoral system for both houses is the simple plurality one. Such a system in such an ethnically, racially, culturally, and socio-economically diverse country in effect prevents the emergence of a multiparty system and the representation of alternative views and policies. Of the old British Commonwealth, although the United States was never a member of it, only Britain and Canada still retain this system, but even in the former the regional parliaments employ the proportionality principle, as do Australia (the Senate), Ireland, New Zealand, and South Africa.

The president is elected under an archaic and grossly flawed electoral system under which the people of each state elect electors who in turn elect a president to which they are pledged to vote, but not legally required. A majority of votes is required in the first round in the Electoral College (Article II, Section 1; Amendment XII; Amendment XX, Sections 3 and 4). It can happen and has happened that the candidate with the most popular votes in the first stage is defeated in the Electoral College, the latest example being in 2000. All attempts to amend the constitution and provide for a popular election of the president, such as in France, Austria (a federal state), and in many Central and South American countries have so far failed.

Criterion 3 stipulates that "politically binding decisions... must be made solely by... democratically legitimated representatives" [2]. There is first of all the problem of low voter turnout in congressional and presidential elections. In the former it has averaged 37 per cent since the 1970s; the last time voter turnout in a presidential election exceeded 60 per cent was in 1968, and the last time it exceeded 70 per cent was in 1900 [20]. There are many factors responsible for non-voting, but a deeply flawed electoral system is an important one. There is also little trust in political institutions. In October, 2011 only 9 per cent approved of the work of Congress and only 10 per cent believed that they could trust the federal government to do the right thing [21]. Here as well there are many factors responsible, but two of the most important ones are governmental deadlocks, especially when a party in opposition to that of the president controls one or both houses of Congress, and the government's unwillingness to seriously address the increasing socio-economic inequality. It cannot therefore be maintained that the representatives are "democratically legitimated.” This matter is further dealt with under Criterion 5 .

Criterion 4 calls for "sufficient separation of state power among several mutually controlling authorities..." [2]. This is certainly true. Indeed, there is the opposite problem of excessive separation of authorities or powers and checks and balances. This undermines at least two of the ten core principles of good governance-accountability and efficiency, advocated by the United Nations [22] and Jain and Jain [4].

Criterion 5 deals with the question of "the extent to which state political power reaches into the social and private spheres" [23]. Here as well the problem is the opposite-a government too weak and unwilling to deal with serious socio-economics problems. The most significant one is the increasing socio-economic inequality and its consequences. The Gini coefficient, measuring income inequality, rose from 0.35 in 1969 to 0.40 in 1992, [24] and in 2011 to 0.475 [25]. The top 1 per cent of the population receives more than 20 per cent of the country's income [26]. It is becoming a plutocracy. According to the 2001 Nobel laureate in economics, the United States "not only has the highest level of inequality among the advanced industrial countries, but the level of inequality is increasing in absolute terms relative to other countries" [27]. The political system "gives inordinate power to those at the top, and they have used that power not only to limit the extent of redistribution but also to shape the rules of the game in their favor, and to extract from the public what can only be called 'gifts'” [28]. 
Socio-economic inequality is also eroding the rule of law [29] and imperilling democracy, because it is unlikely "to achieve a fair and responsive political system within an economic system that is characterized by the degree of inequality that marks ours" [30]. It was therefore not surprising that in 2011 it came to demonstrations against increasing income inequality and an occupation of a park near Wall Street in New York, which became known as the Occupy Wall Street movement. It was an "expression of frustration with the political system..." [31]. Similar occupations of financial districts and political institutions spread around the world.

Criterion 6 considers "how is the exercise of political power regulated?" [23]. There are set terms of office and in effect a permanent and costly election campaign, but insufficiently regulated. Since the 21 January, 2010 United States Supreme Court decision in Citizens United v. Federal Election Commission, corporations and trade unions may spend unlimited funds for political purposes. In a 26 March, 2012 decision by the Washington, D.C. Circuit Court of Appeals individuals may also give unlimited funds to groups, independent of political parties, that advocate the election or defeat of candidates. These decisions have the "potential to create a class of super-wealthy political campaigners with a one-dimensional political interest: enhancing their profits” [32]. In 2011 altogether more than US \$3,200,000,000 was spent on lobbying [33].

\section{Conclusions}

Of the three dominant beliefs, equality of opportunity had become largely a myth by the end of the twentieth century as a result of increasing socio-economic inequality. The importance of individual initiative and responsibility has declined with the coming of the welfare state and the growing realization that an individual alone cannot survive in a globalized and interdependent economic order. Moreover, "alienation has begun to replace motivation" [34]. Since the belief in equality has declined, because of increasing socio-economic inequality, the desire to promote "equality in freedom" abroad has become increasingly limited to freedom alone.

Fundamentally, the constitution and the electoral system have remained as eighteenth century creations, but since then the world has significantly changed. It is no one defect, be it the excessive separation of authorities or powers and the resulting lack of responsible government, or an electoral system providing for a two-party monopoly and the exclusion of alternative views and policies that has been responsible. Rather, the various institutional defects leading to increasing socio-economic inequality and interacting with it have in turn severely undermined confidence and democratic legitimacy of the whole political system and made it a defective democracy.

\section{References}

[1] Merkel, W., et al. (2003) Defekte Demokratie. Leske und Budrich, Opladen, 1, 15.

[2] Merkel, W. and Croissant, A. (2000) Defective Democracies: Concept and Causes. Central European Political Science Review, 1, 32.

[3] United Nations Economic and Social Commission for Asia and the Pacific (2009) What Is Good Governance? Bangkok, 2-3.

[4] Jain, A. and Jain, A. (2011) Impact of Governance of Inclusive Economic Development of a Nation-Some Perspectives. Journal of Political Science, 7, 102.

[5] Merkel, W. and Croissant, A. (2000) Defective Democracies: Concept and Causes. Central European Political Science Review, 1, 34.

[6] Jefferson, T. (1903) The Writings of Thomas Jefferson. In: Lipscomb, A.W., Ed., Thomas Jefferson Memorial Association, Washington DC, 217.

[7] Madison, J. (1961) The Federalist No. 14. In: Cooke, J.E., Ed., The Federalist, World Publishing, Cleveland and New York, 89.

[8] de Tocquiville, A. (1961) Democracy in America. In: Bradley, P., Ed., Vintage Books, New York, 270.

[9] Madison, J. (1961) The Federalist No. 14. In Cooke, J.E., Ed., The Federalist, World Publishing, Cleveland and New York, 351.

[10] Hacker, A. (1970) The End of the American Era. Atheneum Publishers, New York, 210.

[11] Hacker, A. (1970) The End of the American Era. Atheneum Publishers, New York, 142.

[12] Hacker, A. (1970) The End of the American Era. Atheneum Publishers, New York, 139.

[13] Stiglitz, J.E. (2012) The Price of Inequality. Penguin Books, London, 285. 
[14] Morgenthau, H.J. (1964) The Purpose of American Politics. Vintage Books, New York, 57.

[15] Stiglitz, J.E. (2012) The Price of Inequality. Penguin Books, London, xv.

[16] Morgenthau, H.J. (1964) The Purpose of American Politics. Vintage Books, New York, 36.

[17] Morgenthau, H.J. (1964) The Purpose of American Politics. Vintage Books, New York, 5.

[18] Jung, C.G. (1946) The Fight with the Shadow. The Listener, 36, 641.

[19] Merkel, W. and Croissant, A. (2004) Conclusion: Good and Defective Democracies. Democratization, 11, 201.

[20] Patterson, T.E. (2002) The Vanishing Voter: Public Involvement in an Age of Uncertainty. Alfred E. Knopf, New York, 4.

[21] Stiglitz, J.E. (2012) The Price of Inequality. Penguin Books, London, 346.

[22] United Nations Economic and Social Commission for Asia and the Pacific (2009) What Is Good Governance? Bangkok, 3.

[23] Merkel, W. and Croissant, A. (2000) Defective Democracies: Concept and Causes. Central European Political Science Review, 1, 33.

[24] (1994) Inequality. The Economist, November 5, 19.

[25] Worstall, T. (2012) The Amazing Thing about American Inequality: How Equal the Country Is. Forbes, September 22, 1.

[26] Stiglitz, J.E. (2012) The Price of Inequality. Penguin Book, London, 215.

[27] Stiglitz, J.E. (2012) The Price of Inequality. Penguin Books, London, 21.

[28] Stiglitz, J.E. (2012) The Price of Inequality. Penguin Books, London, 32.

[29] Stiglitz, J.E. (2012) The Price of Inequality. Penguin Books, London, 187-206.

[30] Stiglitz, J.E. (2012) The Price of Inequality. Penguin Books, London, 289.

[31] Stiglitz, J.E. (2012) The Price of Inequality. Penguin Books, London, xx.

[32] Stiglitz, J.E. (2012) The Price of Inequality. Penguin Books, London, 131-132.

[33] Stiglitz, J.E. (2012) The Price of Inequality. Penguin Books, London, 95.

[34] Stiglitz, J.E. (2012) The Price of Inequality. Penguin Books, London, 20. 